JPPUMA: Jurnal Ilmu Pemerintahan dan Sosial Politik UMA Uournal of Governance and Political Social

UMA), 7 (2) (2019): 196-208 DOI: http://dx.doi.org/10.31289/ippuma.v7i2.3008

JPPUMA: Jurnal Ilmu Pemerintahan dan Sosial Politik UMA

(Journal of Governance and Political Social UMA)

Available online http://ojs.uma.ac.id/index.php/ippuma

\title{
Peran Kepala Desa dalam Pemilihan Kepala Daerah Kabupaten Deli Serdang Tahun 2018
}

\section{The Role of Village Heads in Deli Serdang District Head Election in 2018}

\author{
Anita Lubis, M Arif Nasution, \& Heri Kusmanto* \\ Magister Ilmu Politik Fakultas Ilmu Sosial dan Politik Universitas Sumatera Utara, Indonesia
}

Diterima: 24 Oktober 2019; Disetujui: 11 November 2019; Dipublikasikan: 01 Desember 2019

\begin{abstract}
Abstrak
Desa merupakan daerah terkecil di struktur pemerintahan Indonesia yang saat ini memiliki peran dan fungsi yang signifikan dalam setiap kegiatan kemasyarakatan, baik dalam konteks politik, sosal, ekonomi maupun hukum. Tujuan penelitian ini adalah untuk menjelaskan bagaimana peran kepala desa dan perangkat desa dalam pelaksanaan pemilihan kepala daerah. Penelitian ini menggunakan metode kualitatif dengan studi kasus. Data didapatkan melalui wawancara mendalam dengan kepala desa, perangkat desa, tokoh masyarakat, dan juga melalui studi literatur. Penelitian ini menarik kesimpulan bahwa peran kepala desa sangat penting dalam pelaksanaan pemilihan kepala daerah, khususnya terkait dengan peningkatan angka partisipasi serta mengelola potensi konflik yang ada di masyarakat dalam kontestasi pemenangan oleh tim kampanye meskipun pilkada dilaksanakan hanya satu pasangan calon melawan kotak kosong. Kampanye tetap dilaksanakan oleh tim pemenangan pasangan calon, bersamaan dengan itu proses sosialisasi dan program peningkatan angka partisipasi pemilih juga tetap dilaksanakan oleh perangkat desa bekerjasama dengan penyelenggara pemilu.

Kata Kunci: Pemerintah Desa, Pemilihan Kepala Daerah, Politik Lokal
\end{abstract}

\begin{abstract}
The village is the smallest area in the Indonesian government structure that currently has a significant role and function in every social activity, both in the political, social, economic and legal contexts. The purpose of this study is to explain how the role of the village head and village apparatus in the implementation of regional head elections. This research uses a qualitative method with case studies. Data were obtained through in-depth interviews with village heads, village officials, community leaders, and also through literature studies. This study draws the conclusion that the role of the village head is very important in the implementation of regional head elections, particularly in relation to increasing the number of participation and managing potential conflicts in the community in the contestation of the campaign by the campaign team even though the election was carried out by only one pair of candidates against the empty box. The campaign will still be carried out by the winning team of candidates, at the same time the process of socialization and the program to increase voter turnout will also continue to be carried out by village officials in collaboration with election commision.
\end{abstract}

Keywords: The Village Government, Local Election, Local Politic

How to Cite: Lubis, A, Nasution, M.A, \& Kusmanto, H. (2019) Peran Kepala Desa dalam Pemilihan Kepala Daerah Kabupaten Deli Serdang Tahun 2018, JPPUMA: Jurnal Ilmu Pemerintahan dan Sosial Politik UMA (Journal of Governance and Political Social UMA), 7 (2): 196-208

*Corresponding author:

ISSN 2549-1660 (Print)

E-mail: anitalubis@gmail.com

ISSN 2550-1305 (Online) 


\section{PENDAHULUAN}

Pemilihan umum mempunyai beberapa fungsi yang tidak bisa dipisahkan satu sama lain. Pertama, sebagai sarana legitimasi politik. Fungsi legitimasi ini terutama menjadi kebutuhan pemerintah dalam system politik yang mewadahi format pemilu yang berlaku. Melalui pemilu, keabsahan pemerintahan ayng berkuasa dapat ditegakkan, begitu pula program dan kebijakan yang dihasilkannya. Dengan begitu, pemerintah, berdasarkan hukum yang disepakati bersama, tidak hanya memiliki otoritas untuk berkuasa, melainkan juga memberikan sanksi berupa hukuman dan ganjaran bagi siapapun yang melanggarnya. Menurut Ginsberg, fungsi legitimasi politik ini merupakan konsekuensi logis yang dimiliki oleh pemilu, yaitu untuk mengubah suatu keterlibatan poltik massa dari yang bersifat sporadis dan dapat membahayakan menjadi suatu sumber utama bagi otoritas dan kekuatan politik nasionaln (Ginsberg, 1982).

Pemilihan kepala daerah secara langsung telah dilaksanakan sejak tahun 2005, yang pada awalnya didasarkan melalui UU No. 32 tahun 2004 tentang Pemerintahan Daerah. Peraturan tentang pilkada terus mengalami perubahan yang bertujuan untuk melakukan penyempurnaan pada penyelenggaraan pilkada. Pilkada saat ini diatur melalui UU No 10 Tahun 2016 tentang perubahan kedua atas UU Nomor 1 Tahun 2015 tentang penetapan peraturan pemerintah pengganti UU Nomor 1 Tahun 2014 tentang pemilihan gubernur, bupati, dan walikota menjadi Undang-Undang.

Paling kurang ada tiga alasan mengapa pemilu bisa menjadi sarana legitimasi politik bagi pemerintah yang berkuasa. Pertama, melalui pemilu pemerintah sebenarnya bisa meyakinkan atau setidaknya memperbaharui kesepakatan-kesepakatan politik dengan rakyat. Kedua, melalui pemilu, pemerintah dapat pula mempengaruhi perilaku rakyat tau warganegara. Tak mengherankan apabila menurut beberapa ahli politik aliran fungsionalisme, pemilu bisa menjadi alat kooptasi bagi pemerintah untuk meningkatkan respon rakyat terhadap kebijakan-kebijakan yang dibuatnya, dan pada saat yang sama memperkecil tingkat oposisi terhadapnya (Haris, 2004; Edelman, 1971; Easton, 1965; Shils, 1962; Rush, 2003). Dan ketiga, dalam dunia modern para pengusa dituntut untuk mengandalkan kesepakatan dari rakyat ketimbang pemaksaan (coercion) untuk mempertahankan legitimasinya (Harris, 1998; Feith, 1999; Hollyson, 2014). Gramsci bahkan menunjukkan bahwa kesepakatan (consent) yang diperoleh melalui hegemoni oleh penguasa ternyata lebih efektif dan bertahan lama sebagai sarana kontrol dan pelestarian legitimasi dan otoritasnya ketimbang penggunaan kekerasan dan dominasi (Gramsci, 1999).

Adapun pemilihan kepala daerah yang dipilih secara langsung dianggap mampu mengembangkan dan membangun daerahnya, selain itu juga merupakan pembagian tugas antara pemerintah pusat dan daerah sehingga dapat menciptakan pembangunan yang berkesinambungan (Syafitri, 2019; Oktavia, 2018; Purba, 2018). Selain itu, pemilihan kepala daerah yang diselenggarakan secara langsung juga dianggap sebagai salah satu indikator adanya demokrasi di Indonesia.

Pada tahun 2018, bersamaan dengan pemilihan Gubernur dan Wakil Gubernur, Kabupaten Deli Serdang juga melaksanakan pemilihan Bupati dan Wakil Bupati. Tidak serupa dengan pemilihan gubernur dan wakil gubernur Sumut yang diikuti oleh dua pasangan calon, yakni Edy Rahmayadi berpasangan dengan Musa Rajekshah dan Djarot Syaiful Hidayat berpasangan dengan Sihar Sitorus, pemilihan Bupati dan Wakil Bupati di Kabupaten Deli Derdang hanya diikuti oleh satu pasangan calon saja, yakni Ashari Tambunan berpasangan dengan Yusuf Siregar. Munculnya hanya satu pasangan calon ini karena seluruh partai politik tidak memberikan dukungan terhadap 
pasangan lain, serta tidak adanya calon perseorangan yang dinyatakan lulus oleh KPUD Deli Serdang untuk mengikuti Pilkada Deli Serdang tahun 2018.

Konsekuensi dari tidak adanya pasangan calon lain yang menjadi penantang di Pilkada Deli Serdang ialah pelaksanaan pilkada dengan satu pasangan calon melawan kotak kosong, hal ini sesuai dengan PKPU Nomor 13 Tahun 2018. Pilkada Deli Serdang Tahun 2018 menjadi menarik karena ternyata hasil penghitungan suara setelah dilakukannya rekapitulasi suara, ditemukan suara yang memilih kota kosong sebanyak 116.193 dengan prosentase sebesar $17,75 \%$ dari total 654.431 suara yang sah. Ternyata meskipun hanya diikuti oleh satu pasangan calon yang melawan kotak kosong, proses sosialisasi dan juga kampanye pemenangan masih menentukan apakah pasangan calon tersebut dapat memenangkan kontestasi tersebut. Karena sesuai dengan aturan yang berlaku, jika pasangan calon mendapatkan suara lebih kecil, atau kalah dari kotak kosong, maka pemilihan kepala daerah akan di ulang kembali dengan tetap memberikan kesempatan kepada pasangan calon yang maju sebelumnya untuk dapat maju kembali. Pilkada yang dimenangkan oleh kotak kosong terjadi di Pemilihan Walikota Makassar tahun 2018. Jadi sebenarnya peran sosialisasi, kampanye dan strategi pemenangan masih sangat relevan dijalankan meskipun hanya diikuti oleh satu pasangan calon, atau meskipun hanya melawan kotak kosong. Berdasarkan rekapitulasi perhitungan suara oleh KPU, pasangan Ashari Tambunan-Ali Yusuf Siregar memperoleh jumlah suara sebanyak $80 \%$ yaitu dari total suara yang saha memperoleh suara sebesar 538.238 atau sebesar $82,25 \%$ dan perlu juga diketahui bahwa partisipasi pemilih di kabupaten Deliserdang juga melebihi dari $50 \%$ yaitu bekisar 58,21\% dan hal ini cukup dianggap baik sebagai proses demokrasi yang berjalan.
Kabupaten Deli Serdang adalah salah satu daerah yang memiliki jumlah desa yang banyak dengan wilayah yang luas serta jumlah pemilih terbanyak setelah kota Medan. Adapun jumlah desa di Kabupaten Deli Serdang adalah 394 desa yang tersebar di 22 kecamatan. Sedangkan jumlah pemilih tetap pada pilkada Deli Serdang pada tahun 2018 adalah sebanyak 1.165.765 Jiwa yang tersebar di 3.379 Tempat Pemungutan Suara (TPS). Dengan jumlah desa yang besar tersebut, maka sangat logis jika suksesnya pemilihan kepala daerah Deli Serdang tahun 2018 sangat tergantung dari peran desa utamanya Kepala Desa bersama dengan para perangkat-perangkatnya.

Menjadikan desa sebagai tolok ukur suksesnya pilkada menjadi sangat penting karena struktur dan kultur pemilih di desa yang lebih homogen, sehingga lebih mudah dipengaruhi oleh tim pemenangan pasangan calon melalui jaringan-jaringan kekuasaan lokal desa. Salah satu cara yang sering dilakukan untuk meraih suara maksimal di desa dalam pemilihan kepala daerah adalah dengan menggunakan perangkat desa atau yang sering disebut sebagai politisasi perangkat desa, utamanya kepala desa sebagai mesin pemenangan pasangan calon. Dengan penguasaan terhadap kepala desa maupun perangkat desa lainnya, maka kerja-kerja politik pemenangan pasangan calon akan semakin ringan dan mudah untuk dipetakan besaran perolehan suara yang ingin dicapai di suatu desa. Dengan posisi sentral dari kepala desa dan potensi yang dimilikinya dalam politik electoral serta kecenderungan para kontestan menggunakan aparat maupun perangkat desa dalam rangka pemenagan, maka posis Kepala Desa dan perangkatnya menjadi vital bagi terselenggaranya pemilihan kepala daerah yang langsung, umum, bebas, jujur dan adil. Jika terjadi politisasi dan hal tersebut secara sengaja dijalankan oleh kepala desa, maka proses demokrasi di tingkat desa akan sangat sulit untuk 
dikembangkan dan berjalan secara optimal.

Pada pilkada Kabupaten Deli Serdang Tahun 2018, beban pemenangan pasangan Ashari Tambunan dan Yusuf Siregar atau pasangan petahana ini sebenarnya tidak terlalu berat mengingat hanya melawan kotak kosong. Selain factor sebagai petahana, hampir seluruh jaringan pemenangan pasangan calon itu juga sudah tersusun rapi di semua daerah. Meskipun demikian, pasangan ini tetap menjalankan program-program pemenangan dan kampanye secara massif ke masyarakat. Dengan bekal sebagai petahana yang memiliki bahan "jualan politik" melalui pembangunan dan program-program yang telah dijalankan pada periode sebelumnya, pasangan ini tetap menjalankan skema pemenangan yang bersifat mainstream seperti melakukan kampanye, sosialisasi dan maksimalisasi jaringan-jaringan penentu di level masyarakat bawah.

Dengan predikat sebagai daerah yang memilih jumlah desa terbesar di Sumatera Utara meneliti lebih jauh terkait dengan peran kepala desa dalam pilkada merupakan tema yang menarik untuk diteliti dan ditemukan jawaban ilmiahnya. Dalam kajian strategi pemenangan, menggunakan jaringan kekuasaan formal di tingkat bawah, khususnya desa merupakan langkah strategis dan sering sekali dijadikan jalan utama dalam pemenangan pilkada maupun pemilu.

Dari latar belakang tersebut di atas, penelitian ini mencoba untuk menjawab Bagaimana peran kepala desa pada Pilkada Deli Serdang Tahun 2018, serta bagaimana keterlibatan Kepala Desa dalam pemenangan pasangan calon Ashari Tambunan dan Yusuf Siregar pada Pilkada Deli Serdang Tahun 2018 di Desa Bandar Khalipah, Kecamatan Percut Sei Tuan, Kabupaten Deli Serdang?

\section{METODE PENELITIAN}

Adapun jenis penelitian ini merupakan penelitian ini adalah penelitian kualitatif. Penelitian kualitatif merupakan sebuah prosedur penelitian yang menghasilkan data deskriptif berupa katakata tertulis atau lisan dari orang-orang dan prilaku yang dapat diamati. Metode kualitatif adalah metode penelitian yang berlandaskan pada filsafat postpositivisme, digunakan untuk meneliti pada kondisi objek yang alamiah, di mana peneliti adalah sebagai instumen utama, (Sugiyono 2010). Metode kualitatif merupakan penelitian yang diangkat dari realitas tertentu yang diinterpretasikan dengan tidak melewati prosedur statistika dan kuantifikasi lainnya, (Ritchie \& Jane, 2004).

Penelitian deskriptif biasanya mempunyai dua tujuan, untuk mengetahui perkembangan fisik tertentu dan mendeskripsikan secara terperinci fenomena sosial tertentu. Menurut (Sugiyono 2013), mengenai jenis-jenis metode penelitian dapat diklarifikasikan berdasar tujuan dan tingkat kealamiahan objek yang diteliti. Sedangkan menurut (Sukmadinata, 2009), penelitian kualitatif adalah penelitian yang digunakan untuk mendeskripsikan dan menganalisis fenomena, peristiwa, aktivitas sosial, sikap, kepercayaan, presepsi, dan orang secara individual maupun kelompok.

Sedangkan menurut (Sukmadinata 2009), menyatakan bahwa penelitian deskriptif bertujuan mendefinisikan suatu keadaan atau fenomena secara apa adanya. Berdasarkan uraian di atas dapat disimpulkan bahwa jenis penelitian ini menggunakan penelitian kualitatif karena analisis datanya berupa kata-kata tertulis atau lisan dan mempertimbangkan pendapat orang lain yang bisa disebut dengan narasumber maupun sumber utama yang dilakukan dalam teknik pengumpulan data. 


\section{HASIL DAN PEMBAHASAN}

Bandar Khalipah merupakan salah satu desa yang terdapat di Kecamatan Percut Sei Tuan Kabupaten Deli Serdang. Secara umum desa ini memiliki luas yang menurut dokumen Laporan Kepala Desa Bandar Khalipahh tahun 2016 sekitar 883 Ha, namun menurut data dari Kecamatan Percut Sei Tuan yang diambil melalui laporan Kecamatan Percut Sei Tuan Dalam Angka pada tahun 2017, desa ini tidak terlalu luas akan tetapi penduduknya sangat banyak tercatat bahwa penduduk di desa ini sekitar 46.701 jiwa dengan laju pertumbuhan $2,11 \%$ tiap tahunnya dimulai dari tahun 2010-2016.

Dalam pemilihan kepala daerah yang dilaksanakan pada tahun 2018 di kabupaten Deli Serdang, desa Bandar Khalipah memiliki pemilih yang terdaftar dalam Daftar Pemilih Tetap (DPT) sebesar 30.247 terdapat 14.555 pemilih yang menggunakan hak pilihnya. Partisipasi pemilih pada pemilihan kepala daerah mencapai 48,12\%, sedangkan jumlah suara tidak sah ada sebesar 1.108. Kemenangan yang diperoleh oleh pasangan Anshari Tambunan dan Yusuf Siregar sebesar $87,38 \%$ dengan perolehan pemilih yaitu 11.750 .

Hasil dan analisa dari penelitian ini adalah tentang peran kepala desa dalam Pemilihan Kepala Daerah (Pilkada) Deli Serdang tahun 2018. Dimana Pilkada tersebut hanya diikuti oleh satu pasangan calon atau dengan kata lain melawan kotak kosong. Walaupun diikuti hanya satu pasangan calon, namun sangat menarik melihat peran kepala desa untuk mensukseskan Pilkada Deli Serdang tahun 2018.

\section{Sosialisasi dan Peningkatan Kesadaran Pemilih di Desa Bandar Khalipah}

Sosialisasi yang dimaksudkan dalam penelitian ini bertujuan untuk memperkenalkan serta mengajak masyarakat untuk turut ikut serta dalam pelaksanaan pemilu serta kegiatan politik lainnya yang ada kaitannya dengan keputusan yang harus diambil oleh pemerintah. Adapun peran kepala desa dalam sosialisasi dan peningkatan kesadaran pemilih di desa Bandar Khalipah yaitu Kepala Desa meningkatkan pemahaman dan pengetahuan masyarakat akan pentingnya pemilu Kepala Daerah dan wakil Kepala Daerah walaupun pemilihan itu hanya diikuti oleh satu pasangan calon saja. Hal itu perlu dilakukan agar kehidupan demokrasi di Indonesia dapat berjalan dengan semestinya.

Proses demokrasi selama ini belum sepenuhnya menggambarkan masyarakat paham akan arti demokrasi. Masyarakat desa yang rata-rata masih berpendidikan rendah memahami politik hanya sebatas pesta rakyat yang dilakukan setiap lima tahun, dan tidak sedikit partisipasi politik yang dilakukan masyarakat masih dipengaruhi oleh adanya gerakan-gerakan dari pihak-pihak yang berkuasa termasuk kepala desa. Kepala desa yang merupakan local strongman mampu memberikan pemahaman kepada masyarakatnya untuk ikut berpartisipasi dalam pemilihan kepala daerah. Apalagi dengan keadaan Pilkada Deli Serdang tahun 2018 yang hanya diikuti hanya 1 pasangan calon saja, ini yang membuat masyarakat beranggapan bahwa tidak perlu hadir di TPS untuk memilih. Pengetahuan masyarakat memilih ataupun tidak memilih tidak akan berpengaruh pada proses pemilihan karena hanya melawan kotak kosong saja. Hal inilah yang sangat perlukan peran kepala desa untuk melakukan sosialisasi secara terus menerus untuk memberikan pemahaman kepada masyarkat di desa Bandar Khalipah.

Sangat perlu peran dari Kepala Desa untuk melakukan sosialisasi kepada masyarakatnya untuk memilih dan memastikan setiap proses dalam pemilihan umum itu dilakukan secara jujur dan adil. Yang dikhawatirkan adalah ketika masyarakat mengetahui Pemilu hanya 
terdiri dari satu calon, masyarakat enggan untuk memilih dengan anggapan mereka memilih dan tidak memilihpun tidak akan berpengaruh terhadap hasil kemenangan calon tersebut. Sehingga partisipasi masyarakat menjadi rendah, jumlah golput meningkat yang kemudian proses demokrasi tidak berjalan dengan baik.

Hal ini disampaikan oleh Pak Suparyo selaku Kepala desa, perannya menentukan jumlah masyarakat yang datang ke TPS. Partisipasi masyarakat 70\%. Peran kepala desa dalam Pilkada yang melawan kotak kosong. Ada 33.000 lebih pemilih. Terkait keterlibatan kepala desa dalam Pilkada, tidak boleh teribat, hanya mendukung dan mensosialisasikan program Bupati yang dirasa baik. (hasil wawancara dengan kepala desa Bandar Khalipah yaitu Bapak Suparyo, SH tanggal 27-09-2019).

Peran kepala desa memastikan bahwa partisipasi masyarakat bisa meningkat dari Pemilihan umum sebelumnya, dan masyatakat mengerti pentingnya mereka untuk datang ke TPS kemudian memilih sesuai dengan pilihan mereka masing-masing tanpa ada unsur paksaan ataupun tekanan dari pihak manapun.

"Sosialisasi yang saya lakukan dengan cara memberikan pemahaman kepada masyarakat untuk mau secara sukareka hadir dan menggunakan hak pilihnya agar prses demokrasi tetap berjalan, walaupun pemilihan hanya melawan kotak kosong saja. Hak suara mereka tetap menentukan siapa yang memimpin Deli Serdang 5 tahun kedepan" (hasil wawancara dengan kepala desa Bandar Khalipah yaitu Bapak Suparyo, SH tanggal 27-09-2019).

Peran kepala desa melakukan sosialisasi untuk meningkatkan partisipasi politik dengan cara mengajak dan menghimbau agar turut serta dalam mensukseskan pemilihan Kepala Daerah (Pilkada), karena peran kepala desa ini sangat penting disamping dia sebagai contoh juga sebagai penggerak massa. Karena partisipasi ini ada beberapa klasifikasinya. Partisipasi bisa bersifat individual atau kolektif, terorganisir atau spontan, mantap atau sporadik, secara damai atau dengan kekerasan, legal atau ilegal, efektif atau tidak efektif.

Menurut Pak herianto selaku tokoh agama, "terkait proses pemilihan dan sosialisasi penilaian saya terhadap pemilukada periode ini banyak yang berperan (perangkat desa dan semuanya), peran untuk mengangkat animo masyarakat untuk datang ke TPS memilih sangat luar biasa, dibandingkan 2014 ke 2018 ini sekarang naiknya 30\%, kalau yang lalu (2014) tidak sampe 50\%" (hasil wawancara dengan tokoh agama yaitu Bapak Herianto tanggal 27-09-2019).

Hasil wawancara di atas dapat dilihat peran kepala Desa Bandar Khalipah dalam hal sosialisasi perihal Pilkada 2018 berjalan dengan baik. Walaupun kompetisi dalam Pilkada kali ini hanya diikitu oleh satu pasangan calon, tetapi animo masyarakat dalam memilih tetap antusias untuk menyampaikan aspirasi politik mereka.

Sosialisai kedua adalah dengan. meningkatkan pemahaman dan pengetahuan masyarakat Desa Bandar Khalipah tentang tahapan dan program pemilu Kepala daerah dan Wakil Kepala Daerah.

"Setiap proses tahapan dalam pemilu kita telah terangkan kepada masyarakat, hal itu perlu kami lalukan agar terus ada animo yang positif untuk menyambut pemilihan kepala daerah. Yang kami khawatirkan masyarakat tidak mendapatkan informasi yang mereka perlukan sehingga mengakibatkan mereka menjadi pasif dalam memilih. Terhadap calon yang ada kami hanya menyampaikan kinerja yang telah mereka lakukan selama mereka memimpin. Walaupun sebenarnya masyarakat sudah tahu mengenai kinerja Bupati yang sekarang ini" (hasil wawancara dengan kepala desa Bandar Khalipah yaitu Bapak Suparyo, SH tanggal 27-09-2019). 
Dari wawancara di atas kita dapat meyimpulkan bahwa peran kepala desa menjadi sentral informasi bagi masyarakat untuk mengetahui tahapan-tahapan Pilkada. Kalaupun ada informasi yang disampaikan seputar pasangan calon bukan merupakan ketidaknetralan dari kepala desa, namun upaya bagi masyarakat untuk mengetahui kinerja pemimpinnya selama ini. Mengenai pemahaman masyarakat terhadap program kerja yang disampaikan oleh pasangan calon, kepala desa bersikap hanya memberikan informasi mengenai profil dari pasangan calon tersebut saja. Seperti yang disampaikan oleh Bapak Suparyo:

"Bupati yang sekarang ini cukup baik bahkan tidak perlu melakukan kampanye masyarakat pun pasti akan memilih beliau, meskipun pada faktanya masih ada yang memilih kotak kosong itulah demokrasi ada pilihan dan pilihan itu memang harus digunakan sebaik-baiknya, arahan atau ajakan bahkan ancaman tidak terjadi pada saat pemilihan Bupati Deli Serdang, dan hal itu tidak pernah terjadi sedari saya menjabat sebagai kepala desa mobilisasi juga tidak dilakukan oleh kepala desa maupun aparat desa di desa ini" (hasil wawancara dengan kepala desa Bandar Khalipah yaitu Bapak Suparyo, SH tanggal 27-09-2019).

Dari hasil wawancara di atas dapat dilihat bahwa proses demokrasi berjalan dengan baik di Desa Bandar Khalipah. Ditunjukan dari pemilih atau masyarakat dapat menyalurkan aspirasi politiknya tanpa ada tekanan atapun paksaan dari pihak manapun. Kepala desa sudah seharusnya bersikap netral dalam memberikan informasi tentang Pilkada dalam upaya menyampaikan informasi yang diperlukan masyarakat.

Meningkatkan pemahaman dan pengetahuan masyarakat tentang hal teknis dalam menggunakan hak politik dan hak pilihnya dengan benar.
Mengenai teknis dalam pemilihan merupakan salah satu kesulitan dan hambatan dari masyarakat untuk memilih. Dengan alasan tidak mengerti ataupun tidak ingin repot, banyak masyarakat yang enggan menggunakan hak politiknya. Disinilah peran dari kepala desa dapat memberikan pemahaman dan pengetahuan kepada masyarakat desa dalam upaya untuk melengkapi syaratsyarat keperluan untuk menggunakan hak politik mereka.

Sosialisasi keempat adalah dengan meningkatkan kesadaran masyarakat khususnya pemilih untuk berperan serta dalam setiap tahapan pemilu Kepala Daerah dan Wakil Kepala Daerah, walaupun Pilkada hanya diikuti oleh 1 pasangan calon saja.

\section{Penyelenggaraan Pilkada Deli Serdang 2018 di Desa Bandar Khalipah}

Undang-Undang Nomor 6 Tahun 2014 Tentang Desa memperkuat kedudukan birokrasi pemerintahan desa, dimana desa diberikan hak yang otonom untuk menjalankan pemerintahannya sendiri. Dan kemudian disebutkan dalam pasal 18 tentang kewenangan desa yaitu beberapa Kewenangan Desa yang meliputi kewenangan di bidang penyelenggaraan Pemerintahan Desa, pelaksanaan Pembangunan Desa, pembinaan kemasyarakatan Desa, dan pemberdayaan masyarakat Desa berdasarkan prakarsa masyarakat, hak asal usul, dan adat istiadat Desa, selanjutnya dalam pasal 26 ayat 1 disebutkan Kepala Desa bertugas menyelenggarakan Pemerintahan Desa, melaksanakan Pembangunan Desa, pembinaan kemasyarakatan Desa, dan pemberdayaan masyarakat Desa. Dengan kewenangan tersebut yang kemudian memberikan kewenangan lebih kepada kepala desa dalam hal menjalankan kekuasaannya sebagai pemimpin tertinggi yang ada di desa.

Peran Kepala Desa sangat penting dalam mensukseskan Pilkada. Kepala Desa 
selalu menjadi garda depan, dimana Kepala Desa terlibat mulai dari pendataan hingga penetapan daftar pemilih tetap (DPT). Kepala Desa Bandar Khalipah mengerti atas tugasnya mensukseskan Pilkada tahun 2018. Tiap penyelenggaraan Pemilu, Komisi Pemilihan Umum (KPU) selalu melakukan evaluasi. Dari hasil evaluasi yang dilakukan pada Pilkada 2018 terdapat adanya perbaikan pada proses penyelenggaraan dilihat dari adanya kenaikan dari jumlah partisipan dan kondisi penyelenggaran yang aman dan tertib, walaupun ada sedikit kesalahan teknik namun masih dapat dimaklumi.

"Pilkada yang dilakukan full team, isu-isu dalam penyelenggaraan tidak ada. Hanya karena dalam system mesti ada pergantian antara PPK dengan KPU, jadi begitu ganti KPU yang baru kebetulan yang lama hanya 1 yang dipertahankan dan 4 dari rekrutmen. Tidak ada pengaruh dalam penyelenggaraan kemarin. Penyelenggaraan pemilu lancar, aman, tertib, wlaupun kekurangan ada dlm salah sasaran dlm pengiriman logistik salah masuk, itu lumrah dikarenakan jumlah TPS yang banyak karena ada 1250 TPS (wawancara dengan Menurut Pak edi santoso, anggota KPPS, tanggal 20 Agustus 2018).

Adanya kerja yang sinergi antara Pemerintah Kabupaten, Kecamatan dan Pemerintahan Desa. Dapat dilihat dari dukungan dari Pemerintah Kabupaten terkait dana Pilkada serentak. Hal ini dibuktikan dalam masalah pergudangan. Karena Kecamatan menfasilitasi juga ada talangan yang cukup karena tempat di Desa Bandar Khalipah tidak cukup untuk menampung kotak suara, karena ada 1250 TPS dikali 5, jadi harus menyewa gudang yang difasilitasi oleh kecamatan dengan cukup baik.

Pengawasan tingkat desa ada semacam mitra kerja (perangkat desa) ada check and balance, tetap menjaga animo masyarakat dalam memilih harus tinggi, lalu hal-hal yang bisa terjadi masalah dilapangan tetap diakomodir melalui anggota KPPS dan pengawas TPS melalui briefing.

Peranan desa dalam pilkada ini desa adalah mitra kpu yang harus mensukseskan Pilkada, hal ini terkait partisipasi pemilih, kehadiran masyarakat dalam pemilu bukan tentang menang atau kalah. Dan juga memfasilitasi calon untuk kampanye, seperti yang diarahkan dalam tata cara kampanye oleh Venus (2004).

Dalam konteks minimalisir konflik, kerusuhan, peranan perangkat desa tidak melakukan hal-hal yang tidak seharusnya dan terlihat netralitas dari perangkatperangkat desa. Kepala desa selalu sebagai pimpinan selalu mengingatkan seluruh perangkat desa untuk dapat memposisikan diri sebagai penyelenggara pemilu yang harus berlaku netral, bukan malah menjadi tim kampanye pasangan calon yang ada. Kondisi saat Pilkada baik calon dan team ada melakukan sosialisasi dan hal lainnya, hanya melalui relawan kampanye bukan dari perangkat desa. Sedangkan dari relawan kotak kosong tidak ada.

\section{Peningkatan Partisipasi Politik Masyarakat di Desa Bandar Khalipah}

Partisipasi merupakan salah salah satu aspek penting demokrasi. Asumsi yang mendasari demokrasi (dan partisipasi) orang yang paling tahu tentang apa yang baik bagi dirinya adalah orang itu ((Amin \& Sembiring; 2018, Sembiring, Kusmanto, \& Pohan, 2018; Suharyanto, 2016; Kusmanto, 2013) Karena keputusan politik yang dibuat dan dilaksanakan oleh pemerintah menyangkut dan mempengaruhi kehidupan warga masyarakat maka warga masyarakat berhak ikut serta menentukan isi keputusan politik" (Surbakti, 1992; Duverger, 2003; Miftah, 2004).

Pemahaman politik merupakan tingkat pengetahuan yang dimiliki oleh seorang atau kelompok masyarakat tentang politik. Pengetahuan yang dimaksudkan disini adalah fungsi dan 
peranannya baik sebagai subjek maupun objek dalam aktivitas politik salah satunya ialah partisipasi politik. (Suharyanto, 2014. Susi, 2015; Purba, 2018; Wardhani, 2018; Ivanna, 2018)

Partisipasi politik mencakup semua kegiatan sukarela melalui mana seseorang turut serta dalam proses pemilihan pemimpin-pemimpin politik dan turut serta secara langsung atau tak langsung dalam pembentukan kebijaksanaan umum. Indikatornya adalah berupa kegiatan individu atau kelompok dan bertujuan ikut aktif dalam kehidupan politik, memilih pimpinan publik atau mempengaruhi kebijakan publik (Budiharjo, 2008).

Sebagai orang nomor satu dalam struktur pemerintah kepala desa mempunyai tugas dan fungsi yang menyeluruh pada berbagai aspek kehidupan pemerintahan desa. Di sisi lain kepala desa sebagai orang yang memiliki aksesibilitas kekuasaan baik keluar maupun kedalam sistem. Oleh karena itu diperlukan kepala desa memiliki peranan penting dalam menumbuhkan meningkatkan dan menggerakkan partisipasi masyarakat desa dengan memberikan arahan binaan ataupun penyuluhan kepada masyarakat desa tentang arti penting pembangunan dan demokrasi bagi kelangsungan hidup masyarakat. Sehingga peran kepala desa sangat signifikan dalam pelaksaan demokrasi di daerahnya, kita dapat melihat peran mereka di desanya dengan melihat jumlah pemilih yang hadir di desa itu menandakan aktif dalam mensosialisasikan pemilihan tersebut. Sehingga tidak jarang yang terpilih merupakan salah satu tokoh yang berpengaruh secara politik dan ekonomi di wilayah tersebut. Sehingga masyarakat mudah menerima arahan binaan ataupun penyuluhan dari kepala desa di wilayahnya, sehingga sejalan dengan tanggapan masyarakat, semakin berperan kepala desa semakin baik pelaksanaan demokrasi di daerah tersebut.
Pak Nasution selaku tokoh masyarakat, memberikan penjelasan terkait kinerja semua yang ada di desa aktif bekerja melalui penjelasanpenjelasan dari dusun-dusun dan sosialisasi ke ibu-ibu pengajian. Pengaruh mobilisasi Ibu-ibu pengajian cukup kuat untuk meningkatkan partisipasi politik. Dengan ungkapan sekarang ini "the power of emak-emak" sangat berpengaruh bagi partisipasi orang-orang disekelilingnya, termasuk anak-anak dan suami mereka. Dan terkait kotak kosong tidak ada gerakan-gerakan khusus. Mobilisasi masyarakat untuk dapat menjalan hak dan kewajibannya sebagai warga negara yaitu dengan datang ke TPS dan memilih tanpa ada unsur paksaan atau dengan cara sukarela.

\section{Netralitas Kepala Desa dalam Pilkada Deli Serdang 2018}

Pemilihan Umum memilih Kepala Daerah biasa dikenal dengan Pemilukada, dimana Pemilihan Umum Kepala Daerah (Pemilukada) adalah Pemilihan Umum untuk memilih Kepala Daerah dan Wakil Kepala Daerah secara langsung di Indonesia oleh penduduk daerah setempat yang memenuhi syarat. Dalam penyelenggaraan Pemilukada, para perangkat Pemerintahan tentulah harus memiliki sikap yang tidak merugikan pihak manapun, khususnya merugikan pihak yang akan mencalonkan diri, namun dalam pelaksanaannya di lapangan, proses pilkada ini banyak sekali ditemukan pelanggaran. Pelanggaran salah satunya dilakukan oleh para bakal calon itu sendiri seperti: money politik, intimidasi, curi start kampanye, kampanye negatif, dan lain sebagainya. Dalam hal ini kepala desa mempunyai peran penting untuk menjaga netralitasnya supaya pelaksanaannya dapat berjalan sesuai dengan aturan dan Undang-Undang Pemilu.

Jika ada keterlibatan kepala desa dalam berpolitik tentunya akan menimbulkan berbagai macam persepsi di 
kalangan masyarakat. Masyarakat yang mempunyai latar belakang yang berbeda baik dalam pendidikan maupun cara berpikir sehingga akan mempunyai anggapan tersendiri terhadap keterlibatan kepala desa dalam politik.

Kepala Desa merupakan salah satu bagian dari Birokrasi Pemerintah yang mana telah diatur dalam Undang-Undang Pemilu, bahwa semua birokrasi pemerintahan tidak boleh terlibat atau mendukung salah satu calon, dan disini salah satunya adalah Kepala Desa yang diharapkan dapat mematuhi aturan Undang-Undang yang berlaku, namun dalam pelaksanaannya masih banyak seorang Kepala Desa menjadi pendukung bagi calon tertentu. Pada pasal 66 ayat 2 bagian C Peraturan Komisi Pemilihan Umum Nomor 7 tahun 2015 ditegaskan dalam kampanye, pasangan calon dan/atau tim kampanye dilarang melibatkan "kepala desa atau sebutan lain/lurah dan perangkat desa atau sebutan lain/kelurahan".

Birokrat yang mempunyai kekuasaan tertinggi ditingkat, dimana kepala desa sangat berperan penting terhadap proses berjalannya pemerintahan desa menuju kesejahteraan masyarakat. Sosok kepala desa merupakan orang yang sangat dihormati di kalangan masyarakat. Selain sebagai pemimpin desa, kepala desa juga merupakan elit lokal yang sangat berpengaruh bagi masyarakat. Besarnya pengaruh kedudukan kepala desa terhadap masyarakat, sering menjadikannya sebagai panutan bagi masyarakat. Dalam menjalankan tugasnya sebagai aparat pemerintah desa, sering terdapat kepala desa yang terlibat politik, dimana ia berperan sebagai penggerak politik masyarakat.

Netralitas kepala desa yang dimaksudkan adalah: pertama, tidak terlibat dalam arti tidak menjadi tim sukses calon kandidat pada masa kampanye atau menjadi peserta kampanye baik dengan menggunakan atribut partai atau menggunakan fasilitas negara. Kedua, tidak memihak dalam arti tidak membantu dalam membuat keputusan dan/atau tindakan yang menguntungkan salah satu pasangan calon, tidak mengadakan kegiatan yang mengarah kepada keberpihakan terhadap salah satu pasangan calon Kepala Daerah/Wakil Kepala Daerah pada masa kampanye meliputi pertemuan, ajakan, himbauan, seruan, atau pemberian barang kepada masyarakat desa, serta tidak membantu dalam menggunakan fasilitas negara yang terkait dengan jabatan dalam rangka pemenangan salah satu calon pasangan Kepala Daerah/Wakil Kepala Daerah pada masa kampanye.

Disinilah Kepala Desa dituntut untuk menjadi seorang pemimpin yang bijaksana supaya masyarakatnya dapat memberikan suatu kepercayaan kepada pemimpinnya, seorang Kepala Desa harus mempunyai suatu upaya dalam menjaga netralitasnya pada pelaksanaan Pemilukada supaya dapat berjalan dengan baik tanpa ada kecurangan dan intimidasi dari pihak manapun. Memberikan contoh yang baik kepada masyarakat dalam proses pemilihan kepala daerah bukanlah suatu perkara yang mudah bagi Kepala Desa, karena akan ada hambatan-hambatannya dalam upaya tersebut. Seperti contoh keadaan perekonomian suatu keluarga, karena perekonomiannya kurang maka akan dengan mudah terpengaruh oleh janji-janji dan juga minimnya pendidikan serta pengetahuan masyarakat sehingga dapat dengan mudah dipengaruhi oleh iming-iming suatu pekerjaan dan pembangunan di daerah tersebut. Dan semua itu menjadi tugas yang berat bagi seorang Kepala Desa dalam upayanya menjaga netralitasnya pada pemilihan umum kepala daerah tersebut.

"sebagai kepala desa memang harus netral, tidak ada arahan dari tim pemenangan ataupun yang terjadi disini bahkan saat kampanye kepala desa juga tidak tau, kalau untuk desa saya ini saya 
hanya membantu dari segi sosialisasi saja kemasyarakat untuk menggunakan hak pilihnya, lalu memantau pembagian formulir C1 karenakan pada saat itu pemilihan Gubernur juga diselenggarakan" (hasil wawancara dengan kepala desa Bandar Khalipah yaitu Bapak Suparyo, SH tanggal 27-09-2019).

Pada dasarnya sesuai dengan peraturan perundang-undangan bahwa kepala desa tidak boleh memihak pasangan calon. Seperti diketahui jika ingin melihat proses demokrasi di Indonesia berjalan maka perhatikan ajang pemilihan kepala desa, dengan pemilu tingkat desa ini merupakan gambaran jelas terhadap proses demokrasi yang berjalan saat ini, apakah rakyat lebih memilih berdasarkan kemampuan atau hanya berdasarkan alasan personal seperti ketokohan atau transaksional. Sesuai dengan Permendagri no 84 tahun 2015 dimaktubkan dalam bagian 2 pasal 6 pada ayat 1 disebutkan kepala desa berkedudukan sebagai kepala pemerintah desa yang memimpin penyelenggaraan pemerintyah desa, pasal 2 menyebutkan kepala desa bertugas menyelenggarakan pemerintahan desa, melaksanakan pembangunan, pembinaan kemasyarakatan dan pemberdayaaan masyarakat.

Kepala Desa mempunyai peran penting dalam kedudukannya sebagai kepanjangan tangan negara yang dekat dengan masyarakat dan sebagai pemimpin masyarakat, sehingga keberadaannya dituntut untuk netral dan dilarang terlibat atau mendukung salah satu calon kepala daerah. Namun, dalam pelaksanaannya, masih banyak oknum kepala desa yang menjadi pendukung dan tim kampanye calon kepala daerah. Selain itu lebih spesifik dalam UU Desa mengatur bahwa Kepala Desa dilarang menjadi pengurus partai politik dan Ikut serta dan atau terlibat dalam kampanye pemilihan umum dan atau pemilihan kepala daerah.
Disebutkan Kepala Desa yang melanggar larangan dapat dikenai sanksi administratif berupa teguran lisan dan atau teguran tertulis. Dalam hal sanksi administratif tidak dilaksanakan, dilakukan tindakan pemberhentian sementara dan dapat dilanjutkan dengan pemberhentian tetap. Dengan demikian Sanksi bagi kepala desa yang mendukung salah satu calon kepala daerah yaitu dapat dikenakan sanksi administratif berupa teguran lisan dan atau teguran tertulis dan lebih berat lagi dapat diberikan sanksi tindakan pemberhentian sementara maupun pemberhentian tetap (Pasal 70 ayat (1) huruf c UU Nomor 10 Tahun 2016).

"Walaupun sekarang cuma melawan kotak kosong. Selaku tokoh agama, terkait dengan politik praktis ternyata sama dengan yang dikatakan kepala desa, terkait hiruk pikuk yang terjadi di PPS dan perangkat desa. Kalau tim sukses jumpain langsung tidak ada, hanya ada himbauan dari KPU jagan sampe berada di zona merah (tekanan kpu berharap dari kpps). Tim2 yg lainnya juga bersih" (hasil wawancara hasil wawancara dengan Pak Herianto selaku tokoh agama tanggal 2809-2019).

Berdasarkan wawancara di atas dapat dimaknai bahwa tidak ada dijumpai dan ada tindakan dari perangkat desa untuk melakukan kecurangan baik itu sifat berpihak kepada salah satu pasangan calon. Baik dari awal tahapan sampai proses akhir pemilihan untuk kampanye pasangan calon hanya dilakukan oleh tim sukses pemenangan dari pasangan calon.

Kampanye yang dilakukan hanya oleh tim pemenangan, tidak ada campur tangan dari kepala dan perangkat desa. Dalam memenangan pasangan kepala daerah, tim melakukan berbagai strategi kampanye dalam memenangkan pasangan kepala daerah, sangat efektif dalam proses pengenalan, pembentukan proses ketersukaan dan sampai pada proses 
dipilihnya Pasangan kepala daerah di tempat pemungutan suara (TPS).

Peran utama dari team pemenangan yang dilakukan calon kepala daerah untuk memperkuat popularitas, elektabilitas secara efisien dengan pengenalan platform pasangan terhadap calon pemilih. Antusiasme serta partisipasi masyarakat di daerah tersebut terhadap pasangan kepala daerah terlihat ketika kampanye sampai pada pemungutan suara berlangsung (Zega, 2018; Putra, 2018). Terlepas dari hal itu semua tugas team pemengan harus dapat menemukan beberapa kekurangan yang harus diperbaiki, oleh karena itu team pemenangan dapat memberikan saran agar dapat mampu melibatkan masyarakat lebih luas lagi misalkan, dengan membangun database dan melakukan aktivasi melalui kegiatankegiatan yang melibatkan partisipasi dan interaksi yang berkelanjutan dengan komunitas, agar didapat prinsip low budget high impact.

\section{SIMPULAN}

Sosialisasi dan peningkatan kesadaran pemilih di Desa Bandar Khalipah, melalui Kepala Desa meningkatkan pemahaman dan pengetahuan masyarakat akan pentingnya pemilu Kepala Daerah dan wakil Kepala Daerah walaupun pemilihan itu hanya diikuti oleh satu pasangan calon saja; meningkatkan pemahaman dan pengetahuan masyarakat Desa Bandar Khalipah tentang tahapan dan program pemilu Kepala daerah dan Wakil Kepala Daerah; meningkatkan pemahaman dan pengetahuan masyarakat tentang hal teknis dalam menggunakan hak politik dan hak pilihnya dengan benar; meningkatkan kesadaran masyarakat khususnya pemilih untuk berperan serta dalam setiap tahapan pemilu Kepala Daerah dan Wakil Kepala Daerah, walaupun Pilkada hanya diikuti oleh 1 pasangan calon saja.

Penyelenggaraan Pilkada Deli Serdang 2018 di Desa Bandar Khalipah, tidak lepas dari peran Kepala Desa sangat penting dalam mensukseskan Pilkada. Kepala Desa selalu menjadi garda depan, dimana Kepala Desa terlibat mulai dari pendataan hingga penetapan daftar pemilih tetap (DPT). Pengawasan tingkat desa ada semacam mitra kerja (perangkat desa) ada check and balance, tetap menjaga animo masyarakat dalam memilih harus tinggi, lalu hal-hal yang bisa terjadi masalah dilapangan tetap diakomodir melalui anggota KPPS dan pengawas TPS melalui briefing. Begitu juga dalam hal peningkatan partisipasi politik masyarakat di Desa Bandar Khalipah, mobilisasi masyarakat untuk dapat menjalan hak dan kewajibannya sebagai warga negara yaitu dengan datang ke TPS dan memilih tanpa ada unsur paksaan atau dengan cara sukarela.

\section{UCAPAN TERIMAKASIH}

Penulis mengucapkan terima kasih kepada Program Magister Ilmu Politik FISIP USU yang telah memberikan kesempatan kepada penulis untuk dapat menyelesaikan penelitian ini dengan baik dan tepat waktu. Seluruh dukungan yang diberikan kepada peneliti sangat berharga dalam menyelesaikan penelitian ini dengan baik.

\section{DAFTAR PUSTAKA}

Amin, M., \& Sembiring, W.M. (2018). Local election: Does bureaucracy become one of main political power? In IOP Conference Series: Earth and Environmental Science (Vol. 126). Institute of Physics Publishing. https://doi.org/10.1088/17551315/126/1/012097

Duverger, M. (2003). Sosiologi Politik. Jakarta, PT Raja Grafindo Persada

Easton, D. (1965). A Systems Analysis of Political Life. New York: Wiley.

Edelman, M. (1971). Politics as Symbolic Action. Chicago: Markham Publishing Co

Feith, H. (1999). Pemilihan Umum 1955, terjemahan Nugroho Katjasungkana dkk. Jakarta, Kepustakaan Populer Gramedia

Ginsberg, B. (1982). The Consequences of consent: Elections, Citizen control and Popular Acquisecence. Mass: Addison-Wesley Publishing 
Harris, S. (1998). Menggugat pemilihan umum orde baru. Jakarta: Yayasan Obor Indonesia

Hollyson, R. (2014). Pilkada (Penuh Euforia, Miskin Makna). Jakarta: PT Raja Grafindo.

Ivanna, J. Pardede, A.J. \& Iqbal, M. (2018). Peran Media Cetak dalam Meningkatkan Partisipasi Politik Di Kelurahan Bandar Selamat Kecamatan Medan Tembung Kota Medan. Journal of Education, Humaniora and Social Sciences (JEHSS). 1 (1): 25-35.

Kusmanto, H., (2013). Peran Badan Permusyawaratan Daerah dalam Meningkatkan Partisipasi Politik Masyarakat, Jurnal Ilmu Pemerintahan dan Sosial Politik, 1 (1): 41-47.

Miftah, T. (2004). Birokrasi dan Politik di Indonesia. Jakarta: PT Grafindo Persada.

Oktavia. M., Prayetno (2018). Menguji Kepemimpinan Kepala Desa dalam Pembangunan Infrastruktur Desa Rianiate Kecamatan Pangururan Kabupaten Samosir. Journal of Education, Humaniora and Social Sciences (JEHSS). 1 (2): 81-92.

Parsons, T. \& Shils. E.A. (1962). Toward A General Theory of Action: Theoretical Foundations for The Social Sciences. Massachusetts: Harvard University Press.

Pito. T.A. (2005). Mengenal Teori-Teori Ilmu Politik. Jakarta, PT Raja Grafindo Persada.

Purba, H.D. Nasution, M.A. \& Warjio (2018), Partisipasi Politik Kader Perempuan Parpol dalam Pilkada di Kabupaten Karo. Anthropos: Jurnal Antropologi Sosial dan Budaya, 4 (1): 23-30

Purba, H.D. Nasution, M.A. \& Warjio (2018), Partisipasi Politik Kader Perempuan Parpol dalam Pilkada di Kabupaten Karo. Anthropos: Jurnal Antropologi Sosial dan Budaya, 4 (1): 23-30

Putra, H. (2018). Mendorong Transparansi dan Akuntabilitas Dana Kampanye pada Penyelenggaraan Pilkada Serentak Tahun 2018. JPPUMA: Jurnal Ilmu Pemerintahan dan Sosial Politik UMA (Journal of Governance and Political Social UMA), 6 (2): 112-121.
Rush, A. (2003). Pengantar Sosiologi Politik. Jakarta. Rajawali Press

Sellers, P.J. (1998). Strategy and Bacground In Congressional Campaigns, (American Political Science Review, Vol. 92, No.1 Maret 1998)

Sembiring, M.W., Kusmanto, H., \& Pohan, Z.S. (2018). Recruitment Model of Political Party for a Political Position in North Sumatera Province, Indonesia. Atlantis Press. https://doi.org/10.2991/icosop-17.2018.101

Suharyanto, A., (2014). Partisipasi Politik Masyarakat Tionghoa dalam Pemilihan Kepala Daerah, Jurnal Ilmu Pemerintahan dan Sosial Politik, 2 (2): 166-175

Suharyanto, A., (2016), Surat Kabar Sebagai Salah Satu Media Penyampaian Informasi Politik pada Partisipasi Politik Masyarakat, Jurnal Administrasi Publik, 6 (2): 123-136.

Sukmadinata, Nana Syaodih. 2009. Metode Penelitian Pendidikan. Bandung: Remaja Rosdakarya.

Susi S dan Adelita L., (2015). Partisipasi Politik Perempuan pada Partai Keadilan Sejahtera Kota Medan, Jurnal Ilmu Pemerintahan dan Sosial Politik, 3 (1): 1-3.

Syafitri, R. Muda, I. \& Matondang, A. (2019). Sistem Penerimaan Badan Ad Hoc Panitia Pemilihan Kecamatan dalam Pemilihan Kepala Daerah pada Komisi Pemilihan Umum Kota Medan. PERSPEKTIF, 8 (2): 72-76.

Venus, A. (2004). Manajemen Kampanye: Panduan Teoritis dan Praktis Dalam Mengaktifkan Kampanye Komunikasi. Bandung: Simbiosa Rekatama

Wardhani, P.S.N. (2018). Partisipasi Politik Pemilih Pemula dalam Pemilihan Umum. Jurnal Pendidikan Ilmu-Ilmu Sosial, 10 (1): 57-62.

Zega, M.A. Muda, I. Batubara, B.M. \& Suharyanto, A. (2018). Pengaruh Program Rumah Pintar Pemilu Terhadap Partisipasi Politik Masyarakat Pada Kantor Komisi Pemilihan Umum Kota Medan, PERSPEKTIF, 7 (2): 6065. 